\title{
Kangaroo-mother care method: a documentary study of theses and dissertations of the brazilian nurse (2000-2017)
}

\author{
Método canguru: estudo documental de teses e dissertações da enfermagem brasileira (2000-2017)
}

Método madre-canguro: estudio documental de tesis y disertaciones de enfermería brasileña (2000-2017)

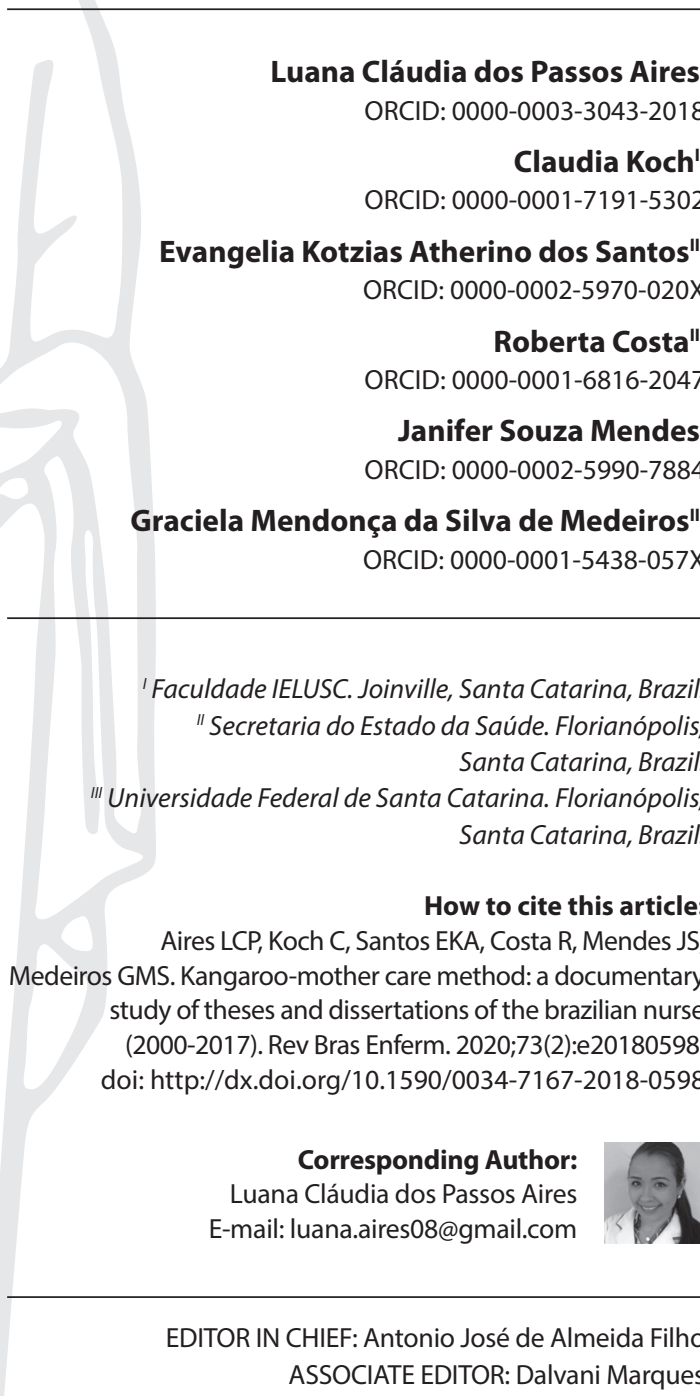

Submission: 08-06-2018

Approval: 09-09-2018

\begin{abstract}
Objectives: to characterize theses and dissertations that address Kangaroo-Mother Care Method produced in Brazilian Graduate Nursing Programs from 2000 to 2017. Methods: a documentary study of qualitative approach. From a total of 207 papers, 185 were excluded and 22 were selected. Results: in 2006 and 2014 there was a higher number of master's dissertations. In 2001, 2013 and 2017, there were three productions of doctoral theses. Universidade Federal de Santa Catarina (Federal University of Santa Catarina) presented the largest number of publications, with five studies, followed by Universidade Federal da Bahia (Federal University of Bahia), with four. Final considerations: Kangaroo-Mother Care Method has been researched in Brazilian Graduate Nursing Programs, mainly from the qualitative approach, highlighting the importance, contributions and difficulties of its application as a public policy.

Descriptors: Kangaroo-Mother Care Method; Neonatal Nursing; Intensive Care Units Neonatal; Nursing Research; Academic Dissertations.
\end{abstract}

\section{RESUMO}

Objetivos: caracterizar as teses e as dissertações que abordam a temática do Método Canguru, produzidas nos Programas de Pós-Graduação em Enfermagem do Brasil, no período de 2000 a 2017. Métodos: estudo documental de abordagem qualitativa. De um total de 207 trabalhos, 185 foram excluídos e 22 selecionados. Resultados: no ano de 2006 e 2014 houve maior número de dissertações de mestrado. Nos anos de 2001, 2013 e 2017 houve três produções de teses de doutorado. A Universidade Federal de Santa Catarina apresentou maior número de publicações, com cinco estudos, seguida da Universidade Federal da Bahia, com quatro. Considerações finais: o Método Canguru vem sendo pesquisado nos Programas de PósGraduação da Enfermagem no Brasil, a partir principalmente da abordagem qualitativa, destacando a importância, as contribuições e as dificuldades da aplicação do mesmo enquanto política pública.

Descritores: Método Canguru; Enfermagem Neonatal; Unidades de Terapia Intensiva Neonatal; Pesquisa em Enfermagem; Dissertações Acadêmicas.

\section{RESUMEN}

Objetivos: para caracterizar lastesis y disertaciones que abordenel tema del Método MadreCanguro, producido en los Programas de Posgrado en Enfermería en Brasil, de 2000 a 2017. Métodos: estudio documental de enfoque cualitativo. De un total de 207 artículos, 185 fueron excluidos y 22 seleccionados. Resultados: en 2006 y 2014 hubo un mayor número de disertaciones de maestría. En los años 2001, 2013 y 2017 hubo tres producciones de tesis doctorales. La Universidade Federal de Santa Catarina (Universidad Federal de Santa Catarina) presentó el mayor número de publicaciones, con cinco estudios, seguida de la Universidade Federal de Santa Catarina (Universidad Federal de Bahía), con cuatro. Consideraciones finales: el Método Madre-Canguro ha sido investigado en los Programas de Posgrado en Enfermería en Brasil, principalmente desde el enfoque cualitativo, destacando la importancia, las contribuciones y las dificultades de sua plicación como política pública.

Descriptores: Método Madre-Canguro; Enfermería Neonatal; Unidades de Cuidado Intensivo Neonatal; Investigación em Enfermería; Tesis Académicas. 


\section{INTRODUCTION}

Preterm and low birth weight infants are children born at 36 weeks and 6 days of gestation, weighing less than 2,500 $\mathrm{g}$ at birth, respectively ${ }^{(1)}$. This number accounts for about 20 million low birth weight preterm infants worldwide. Of this population, approximately one third die before the age of one ${ }^{(1)}$.

High perinatal morbidity and mortality rates, especially in the poorest regions, are a public health problem. They are mainly due to respiratory problems, asphyxiation at birth, infections, metabolic disorders and difficulties in eating and regulating body temperature ${ }^{(2)}$.

Created in Colombia in 1979 by the InstitutoMaternolnfantil [Mother and Child Institute] in Bogotá, Kangaroo-Mother Care Method (KMCM) is an effective health technology. It was initially conceived as an alternative to the overcrowding of Neonatal Units (NU), aiming to address the lack of incubators. Disseminated in several countries, KMCM presents in Brazil a special conjuncture aimed at humanization, encouraging the involvement of parents in child hospitalization process and increasing maternal satisfaction with newborn (NB) care. It ranges from the requirements of biological care and specialized technical care to aspects of psycho-affective care, with equal emphasis ${ }^{(2-4)}$.

Widely known for early skin-to-skin contact between baby and family members for bond strengthening, KMCM corresponds to a paradigm shift in perinatal care. It covers environmentally friendly care for the protection and development of the premature brain, as well as reducing the risk of severe infection/sepsis and the mortality rate at discharge such as increasing breastfeeding, weight gain and height rates ${ }^{(2-4)}$.

It is organized into three stages, the first being in the Neonatal Intensive Care Unit (NICU) and the Conventional Neonatal Intermediate Care Unit (UCINCo - Unidade de Cuidadolntermediário Neonatal Convencional); the second in the Kangaroo Neonatal Intermediate Care Unit (UNINCa - Unidade de Cuidadolntermediário Neonatal Canguru); and the third after hospital discharge, at home ${ }^{(2,3)}$.

In this context, KMCM in Brazil is gaining strength and constitutes an important public health policy based on the Humanized Care Standard for Low-Weight Newborns (Norma de AtençãoHumanizada aoRecém-Nascido de Baixo Peso) through Ordinance 693 of July $5,2000^{(5)}$. In recent years KMCM has been expanded and strengthened in our country with a view to incorporating it into various national pacts, initiatives and policies that support NB care network organization ${ }^{(2-3,5-10)}$.

In view of encouragement and government support, importance recognition of this policy for the survival and quality of care for preterm and low birth weight infants, possibilities of action of the nursing team and contributions that Graduate Nursing Programs through Stricto Sensu courses can offer (addressing this theme in their paper), as well as theme relevance to nursing, the following question emerged: what are the characteristics of doctoral theses and master's dissertations produced by Brazilian Graduate Nursing Programs addressing KMCM?

\section{OBJECTIVES}

To characterize theses and dissertations that address KMCM produced in the Brazilian Graduate Nursing Programs from 2000 to 2017.

\section{METHODS}

\section{Ethical aspects}

As this is a documentary research that uses public domain information, there was no need for submission to the Research Ethics Committee, according to Resolution 466/12 and the Brazilian National Health Board (Conselho Nacional de Saúde) guidelines.

\section{Design, place of study and period}

This is a qualitative documentary study, which has as technique the reading, selection, filing and archiving of topics of interest for the research in question, in order to know the scientific contributions that were made on a given subject. Documentary research has been widely used in this research, with emphasis on humanities and social sciences. It enables the historical reconstruction of a given context, as well as configuring an important data source for various types of research ${ }^{(11-12)}$.

This research was conducted in June 2018 through the Theses and Dissertations Catalog of CAPES (Coordenação de Aperfeiçoamento de Pessoal de Nível Superior - Coordination of Higher Education Personnel Improvement). It is available online at the website $^{(13)}$ from the use of keywords "kangaroo mother", "kangaroo mother method", "kangaroo-mother care method". It is important to highlight that study search was performed by peer review, ensuring the scientific rigor required in documentary analysis approaches.

\section{Population or sample, andinclusion and exclusion criteria}

The search period from 2000 to 2017 was delimited as a search period. This cut-off is justified by Ordinance 693 of July 5, 2000, which, based on the Humanized Care Standard for Low-Weight Newborns, establishes KMCM as a public health policy ${ }^{(5)}$.

The keywords were chosen because of the Colombian origin of the "Programa Madre Canguro" Method. The name "KangarooMother Care Method" is still used in many countries. In Brazil, from its formalization as a government policy, the Method had its nomenclature adapted into Método Canguru because it comprises a care policy to the NB's entire family nucleus.

As inclusion criteria, we adopted health productions developed exclusively in Stricto Sensu Graduate Nursing Programs; papers whose year of defense were among the selected cut-off from 2000 to 2017; papers whose abstracts were found in CAPES'Theses and Dissertations Catalog or in the Graduate Program Repository of origin. We excluded papers that were duplicate, being considered in only one keyword or that KMCM was not addressed in the theme.

For cases in which papers were included in CAPES'catalog after the Sucupira Platform (Plataforma Sucupira), i.e., without abstracts available online, search strategies were adopted through the Graduate Program Repository to which it belongs, or contact via e-mail with the corresponding author. Nine papers were excluded that despite searching from the selected keywords did not address KMCM. It was also excluded a paper in which the abstract was not available, after contact with the advisor reporting that the paperhad not been completed. 
Among the papers excluded because they belong to different Graduate Programs, we highlight the fields of medical sciences, medicine, speech therapy, psychology, physiotherapy, public health, public health, health promotion, nutrition, among others.

\section{Analysisof results and statistics}

For data compilation, a spreadsheet was prepared by using the Microsoft Excel ${ }^{\circ}$ program. It contained paper title; year of defense; Graduate Program; author; resume; type of study; theoretical framework; methodological framework; data collection tool; and main outcomes. The next step consisted of the analytical reading of all abstracts, articulated with the available literature that provided support for the discussion of results.

\section{RESULTS}

From the search of the listed keywords, we found the papers described in Figure 1 .

Of the 22 papers included in the analysis, three were doctoral dissertations and 19 were master's dissertations. These findings can be seen in Chart 1 and Figure 2 presented below.

The theses and dissertations were analyzed from 2000 to 2017. Observing Figure 2, it can be seen that 2006 and 2014 concentrated the largest number of papers, being master's dissertations. Regarding doctoral theses, there were only three productions, corresponding to 2004, 2013 and 2017. In this interval, which corresponds to 17 years of analysis of the productions, it is observed that five years did not present any study in the Graduate Nursing Degree on the theme.

Regarding the institutions where the studies were conducted, those that occupy the most prominent place in the productions are Universidade Federal de Santa Catarina, with five papers and Universidade Federal da Bahia, with four. It is noteworthy that most productions are concentrated in the Northeast, Southeast and South of the country, with a percentage of $37 \%, 32 \%$ and $27 \%$ respectively. Center-West totals $5 \%$, and North did not produce this search on the theme.

Regarding the study design, 18 studies identified and analyzed used the qualitative approach; three studies were quantitative and one mixed. The number of participants in the studies ranged from 8 to 150, and these health professionals (nurses, nursing technicians, physicians, nursing assistants and attendants) NU staff, mothers, fathers, families.

Among the main theoretical frameworks used for the analysis of qualitative research are Humanized Care Standard for LowWeight Newborns - KMCM; Family-Centered Care; Paulo Freire's Liberation Pedagogy; Attachment Theory; Adaptation Theory; Symbolic Interactionism; Sister Callista Roy's Adaptation Model; Health Care Networks; Edgar Morin's Theory of Complexity and Heideggerian thinking expressed in Being and Time. Of the qualitative approaches, six authors do not describe in their abstracts the type of framework used.

Regarding the methodological framework, they were mainly referenced for the treatment of qualitative data: Grounded Theory (GT); Problematizing Methodology with Maguerez's Arch; Convergent Care Research (PesquisaConvergenteAssistencial); Lefèvre's Discourse of the Collective Subject; Paulo Freire's Liberation Pedagogy and Cartography; Bardin and Minayo's Thematic Analysis.

For the quantitative analyzes, programs such as Qualiquantisoft software were used. Epi Info,tools, Likert-scale type, Statistical Package for Social Sciences (SPSS) software version 13.0 and version 21.0 were also used. Chi-Square and Fisher's Exact Test, descriptive statistical analysis and consensus analysis based on the last step of the modified Delphi technique, census, cross-sectional survey study using the KAP (Knowledge, Attitude, Practice) Methodwere performed. Data were analyzed by the R statistical program (simple percentage, mean and confidence intervals $(\mathrm{CI}))$.

Research data collection techniques include interviews (semistructured, focused, phenomenological and in-depth), observation (participant, descriptive), workshops (educational and reflection, elaboration of genograms and ecomaps, medical record consultations, questionnaires,Swot Matrix, and field diary.

The outcomes found in thesis and dissertation abstracts addressing KMCM were also analyzed as a way to identify which sub-themes inherent to the subject are of interest to researchers. The analysis of the outcomes showed the existence of six categories, presented below in Table 1.

These results provide an overview of how KMCM is perceived and used in nursing. They provide also if its potentialities are being explored, the practical implications of its use, among other study possibilities and knowledge gaps.

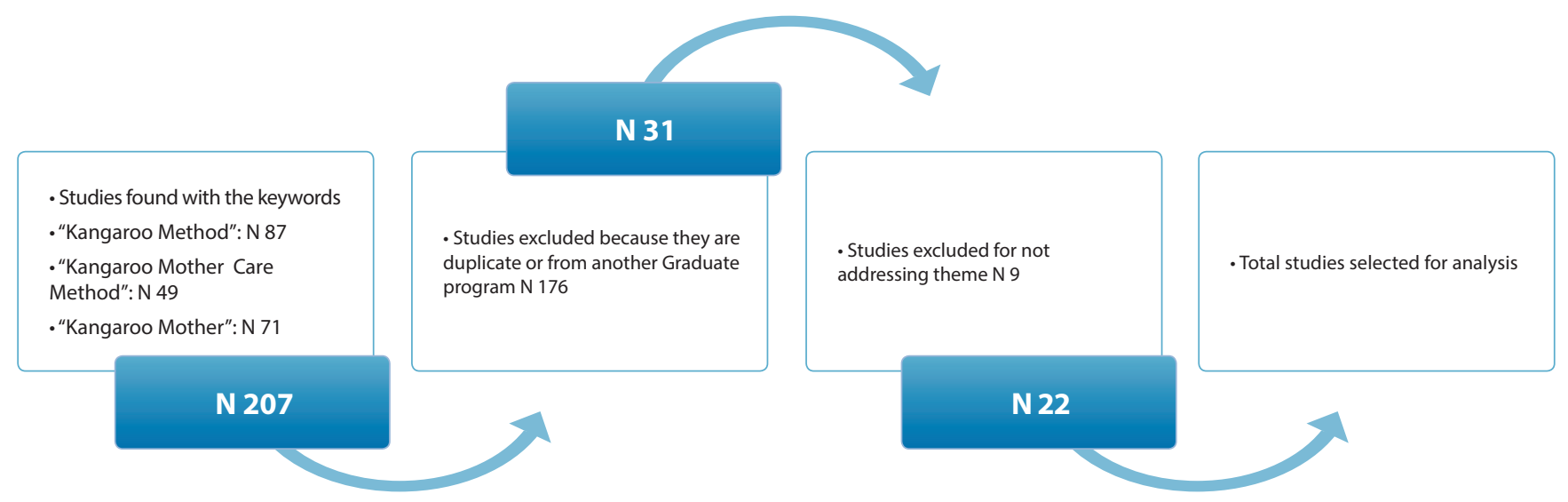

Figure 1 - Number of papers found, deleted, and selected by keyword. Florianopolis, 2018 
Chart 1 -List of papers included by title, year of defense and Graduate Nursing Program of origin, Florianópolis, Santa Catarina, Brasil, 2018

\begin{tabular}{|c|c|c|c|}
\hline $\mathbf{N}^{\circ}$ & Papertitle & Year & GraduateProgram \\
\hline 1 & $\begin{array}{l}\text { Conhecimento, aceitação e disponibilidade dos profissionais de saúde sobre o método } \\
\text { mãe canguru em unidade neonatal de um hospital universitário do município de São } \\
\text { Paulo }{ }^{(14)}\end{array}$ & 2001 & Universidade Federal de São Paulo \\
\hline 2 & $\begin{array}{l}\text { Implantação do Método Mãe-Canguru: percepção do enfermeiro e dos pais sobre a } \\
\text { vivência }{ }^{(15)}\end{array}$ & 2002 & Universidade de São Paulo-Sp \\
\hline 3 & Vivendo no método canguru: a tríade mãe-filho-família ${ }^{(16)}$ & 2004 & Universidade de São Paulo - Ribeirão Preto \\
\hline 4 & Método mãe-canguru: evolução ponderal de recém-nascidos ${ }^{(17)}$ & 2005 & Universidade Federal da Bahia \\
\hline 5 & $\begin{array}{l}\text { Reflexões da equipe de saúde sobre o método mãe-canguru em uma unidade de } \\
\text { neonatologia: um diálogo fundamentado na abordagem problematizadora }{ }^{(18)}\end{array}$ & 2005 & Universidade Federal de Santa Catarina \\
\hline 6 & O sentido do ser-mulher-puérpera no Método Mãe Canguru ${ }^{(19)}$ & 2006 & Universidade Federal da Bahia \\
\hline 7 & $\begin{array}{l}\text { Avaliação normativa da implantação do Método Canguru na Maternidade Odete } \\
\text { Valadares, Belo Horizonte, Minas Gerais }\end{array}$ & 2006 & Universidade Federal de Minas Gerais \\
\hline 8 & $\begin{array}{l}\text { A formação do apego pais/recém-nascido pré-termo e/ou de baixo peso no método } \\
\text { mãe-canguru: uma contribuição da enfermagem }{ }^{(21)}\end{array}$ & 2006 & Universidade Federal de Santa Catarina \\
\hline 9 & $\begin{array}{l}\text { Encontros Afetivos Entre Pais e Bebê no espaço relacional da Unidade Neonatal: um } \\
\text { estudo de caso à luz do Método Mãe-Canguru (22) }\end{array}$ & 2007 & Universidade Federal do Estado do Rio de Janeiro \\
\hline 10 & $\begin{array}{l}\text { Terceira Etapa do Método Mãe-Canguru: convergência de práticas investigativas e } \\
\text { cuidado no processo de adaptação de famílias com recém-nascidos pré-termo e/ou } \\
\text { de baixo peso }{ }^{(23)}\end{array}$ & 2007 & Universidade Federal de Santa Catarina \\
\hline 11 & Cuidado à Criança Prematura no Domicílio (24) & 2008 & Universidade Federal da Bahia \\
\hline 12 & O sentido do cuidado para mães no método canguru ${ }^{(25)}$ & 2011 & Universidade Federal do Piauí \\
\hline 13 & $\begin{array}{l}\text { Sendo um Multiplicador de Valores e Práticas para a (Des)Continuidade do Método } \\
\text { Canguru na Unidade de Terapia Intensiva Neonatal: subsídios para a gerência do } \\
\text { cuidado de enfermagem }{ }^{(26)}\end{array}$ & 2013 & Universidade Federal do Rio de Janeiro \\
\hline 14 & Significado para mães sobre a vivência no Método Canguru ${ }^{(27)}$ & 2014 & Universidade Federal da Bahia \\
\hline 15 & $\begin{array}{l}\text { O acolhimento materno no contexto da prematuridade em um Hospital Amigo da } \\
\text { Criança(28) }\end{array}$ & 2014 & Universidade de São Paulo - Ribeirão Preto \\
\hline 16 & $\begin{array}{l}\text { Algoritmos de cuidado de enfermagem fundamentados no método canguru: uma } \\
\text { construção participativa }^{(29)}\end{array}$ & 2014 & Universidade Federal do Paraná \\
\hline 17 & $\begin{array}{l}\text { Participação materna no método canguru ao recém-nascido pré-termo muito baixo } \\
\text { peso internado na unidade de terapia intensiva neonatal(30) }\end{array}$ & 2015 & Universidade de Pernambuco \\
\hline 18 & $\begin{array}{l}\text { Percepções dos profissionais de saúde da atenção básica sobre o seguimento do } \\
\text { bebê pré-termo e/ou baixo peso e à sua família: interfaces com a terceira etapa do } \\
\text { Método Canguru }{ }^{(31)}\end{array}$ & 2015 & Universidade Federal de Santa Catarina \\
\hline 19 & $\begin{array}{l}\text { Alta Hospitalar do Recém-Nascido submetido ao Método Canguru: contribuições da } \\
\text { enfermagem }^{(32)}\end{array}$ & 2016 & Universidade Federal do Piauí \\
\hline 20 & Método Canguru: a experiência dos pais de recém-nascidos com baixo peso ${ }^{(33)}$ & 2017 & Universidade Federal de Mato Grosso do Sul \\
\hline 21 & Método Canguru: (Des) Atenção ao binômio mãe-bebêna estratégia saúde da Família(34) & 2017 & Universidade Federal da Paraíba \\
\hline 22 & $\begin{array}{l}\text { Cuidado compartilhado do Método Canguru na atenção básica de saúde em } \\
\text { Florianópolis(35) }^{(35)}\end{array}$ & 2017 & Universidade Federal de Santa Catarina \\
\hline
\end{tabular}

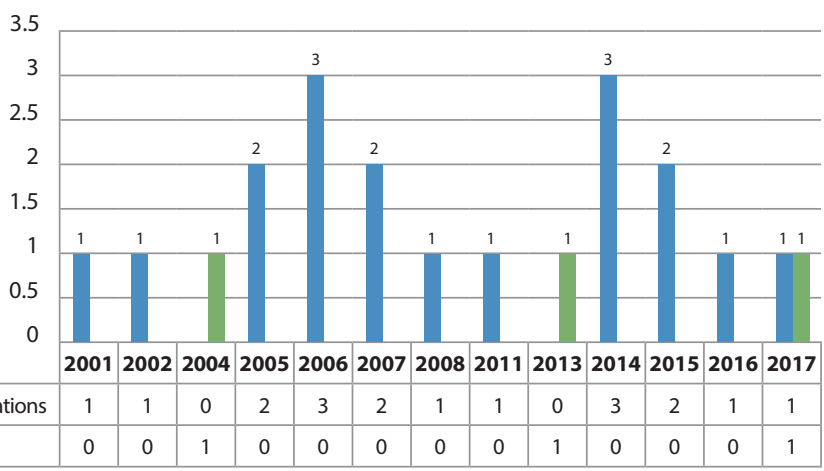

Figure 2 - Distribution of doctoral theses and master's dissertations of Brazilian Graduate Nursing Programs addressing Kangaroo-Mother Care Method according to year, Florianópolis, Santa Catarina, Brasil, 2018

\section{DISCUSSION}

The analysis of the selected theses and dissertations, defended in from 2000 to 2017, showed that KMCM formalization as a public health policy reflected in interest for scientific research in nursing on the subject. The first KMCM-related studies in Graduate Nursing Programs began in 2001, one year after the launch of the Humanized Care Standard for Low-Weight Newborns - KMCM(5).

It is interesting to note that, despite the change in nomenclature, many authors still referred to Kangaroo-Mother Care Method as Kangaroo Mother Method until 2011. For a long time, there was not a 
Table 1 -Main outcomes of doctoral theses and master's dissertations of Graduate Nursing Programs addressing KMCM, according to focus, research and results, Florianópolis, Santa Catarina, Brasil, 2018

\begin{tabular}{|c|c|c|}
\hline Focus & Investigation & Results \\
\hline 1- Family & $\begin{array}{l}\text { - Knowledge } \\
\text { - Experiences }\end{array}$ & $\begin{array}{l}\text { - Fears, insecurities } \\
\text { - Support network }\end{array}$ \\
\hline 2- Health professionals & $\begin{array}{l}\text { - Perceptions } \\
\text { - Feelings } \\
\text { - Actions that develop } \\
\text { - Meanings } \\
\text { - EducationalActions }\end{array}$ & $\begin{array}{l}\text { - Fears, insecurities } \\
\text { - Need to create spaces for reflection }\end{array}$ \\
\hline 3 - Firststage & $\begin{array}{l}\text { - Attachment } \\
\text { - Analysis of factors intervening in maternal participation in } \\
\text { Kangaroo care }\end{array}$ & $\begin{array}{l}\text { - Coping with prematurity } \\
\text { - Establishment of bond } \\
\text { - Human, material or infrastructure weaknesses }\end{array}$ \\
\hline 4 - Secondstage & $\begin{array}{l}\text { - The sense of being a woman in KMCM } \\
\text { - Analysis of weight evolution of babies }\end{array}$ & $\begin{array}{l}\text { - Need to welcome the woman/mother } \\
\text { - Follow-up of weight evolution }\end{array}$ \\
\hline 5-Thirdstage & - Care follow-up in Primary Care and interfaces with KMCM & $\begin{array}{l}\text { - Hospital discharge of NB undergoing KMCM } \\
\text { - Referral and counter-referral } \\
\text { - Strengthen communication } \\
\text { - Home care } \\
\text { - Establishment of nursing consultation }\end{array}$ \\
\hline 6- Politics & - KMCMestablishmentassessment & - Need for managerial and political incentive to strengthen KMCM \\
\hline
\end{tabular}

Note: KMCM: Kangaroo-Mother Care Method; NB: newborn.

Portuguese descriptor referring to Kangaroo-Mother Care Method. The descriptor initially used was MétodoCanguru (Kangaroo Mother Method), which, for Brazilian authors, was characterized by a bias in their paper. Currently we find in the DeCS (Health Sciences Descriptors) the descriptor "Kangaroo-Mother Care Method"(3).

In the 17-year search period, production gaps for 2000, 2003, 2009, 2010 and 2012 are related to important milestones in the country's public policy history. The Millennium Development Goals were initiated in the $2000 s^{(36)}$ as well as the Humanized Care Standard for Low-Weight Newborns - $\mathrm{KMCM}^{(5)}$ and the Brazilian National Prenatal and Birth Humanization Program (Programa Nacional de Humanização no Pré-Natal e Nascimento)(36-37).In 2003 the Brazilian National Humanization Policy (Política Nacional de Humanização) was launched ${ }^{(2)}$. In 2009 the Ministry of Health instituted the Strategy Healthy Brasileirinhos and Brasileirinhas, and the following year the Health Care Networks (RAS - Redes de Atenção à Saúde)(36). In 2012 is published Ordinance 930, which defines guidelines and objectives for the organization of comprehensive and humanized care to severe or potentially severe NB and the criteria for classification and qualification of SUS (Sistema Único de Saúde - Brazilian Unified Health System) NU beds ${ }^{(7)}$. However, as the corpus of analysis was composed only of abstracts of productions, we cannot say exactly what is the justification for the production gaps in these years.

The first StrictoSensu Graduate Nursing courses in Brazil were established in the South, Southeast and Northeast regions of the country. This denotes production prominence in the institutions of these regions. The fact that more dissertations are identified than theses using KMCM may be related to the fact that the number of nursing master's degree courses is longer and started in the country in the 1970s. In contrast, doctoral courses emerged in the country in the early $1980 s^{(38-39)}$. Master's degree courses still have a shorter duration when compared to doctoral programs, resulting in a larger number of dissertations in relation to theses.
Universidade Federal de Santa Catarina featured prominently in the scientific production related to the theme, with five papers (four dissertations and one thesis). This finding is probably influenced by the profile of researchers in their research groups, with many KMCM tutors and consultants. The university in question has an attached University Hospital, which became a Brazilian reference for KMCM in 2001. This is a determining factor for the development of investigations involving the theme analyzed ${ }^{(3)}$.

Regarding the predominance of qualitative approach in investigations, a similar finding was identified in a study that analyzed the production of doctoral theses in nursing in Brazil ${ }^{(39)}$. It is necessary that nursing appropriates clinical investigations that analyze the advantages of KMCM from scientific evidence in randomized studies.

Non-description of the theoretical frameworks adopted in all studies may have occurred due to the fact that only abstracts were analyzed, and not the full paper. However, the variety and density analyzed indicate the importance that Graduate Nursing Programs have given to proper theoretical foundation of qualitative analyzes. Diverse data collection techniques, prioritizing triangulation, give quality to qualitative research.

Studies of theses and dissertations showed concern to support, assess and promote KMCM, understand the experiences, perceptions, meanings and adaptation processes of mothers/fathers and family members regarding preterm and/or low-weight NB care, as well as how to explain the perception and participation of professionals in this policy.

Studies were found in the three steps of the Method. The main outcomes evidenced correspond to: 1) First stage: related to NB hospitalization process and establishment of bond between the family, attachment formation, inclusion in care ${ }^{(22-33)}$; 2) Second stage: related to the preparation of the family for hospital discharge, being the mother who experiences the method, and the weight evolution of babies ${ }^{(17,19)}$; 3) Third stage: related to the challenges of home care, the weak referral and counter-referral 
between health services, nursing consultation and strategies for

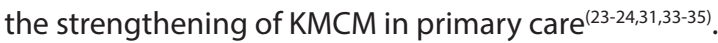

There is a change in the focus on research, initially bringing the mother as protagonist, and later prioritizing family-centered care $^{(18,40)}$. Research reinforces the benefits of KMCM for children, mainly corresponding to bonding, early performance of maternity and paternity ${ }^{(15-16,19,21-25,27-28,30-34)}$, favoring secure attachment ${ }^{(21-22)}$.

Preterm baby care is predominantly focused on the biomedical and curative model. The participation of primary care professionals in KMCM is still shy and preterm and/or low-weight NB care permeated with insecurity ${ }^{(31,41)}$. The results show the need to strengthen the role of the family in early hospitalization (third stage), review discharge criteria, ensure all possibilities of continued care ${ }^{(32-33,42)}$.

There must be educational actions that favor practices to be reviewed, providing moments of reflection on the actions developed by health professionals in this context. Understanding their perceptions are strategies for the successful establishment of the method(14,18,26,29-32,35).

A safe and sensitive team with this methodology more easily overcome the barriers related to human, material or infrastructure weaknesses experienced in most hospitals. Working with $\mathrm{KMCM}$ requires a professional profile to meet families in their entirety and individuality.

It is important for NU professionals to understand mothers who experience the hospitalization of their preterm child, their difficulties leaving home, husband and other children in order to live 24/7 with their baby in the Kangaroo ward care ${ }^{(27,43)}$. Postpartum women in KMCM goes through interpretations and senses of a mother who needs to take care of her child, and the newly delivered woman who is equally in need of care is often overlooked $^{(19,40)}$. This experience will influence the maternal conception on its importance in this process and mainly by the form that is included in it. The support network available to the family, whether professional or affective, is of fundamental importance in care ${ }^{(44)}$.Therefore, methodologies that reinforce carrying out family-centered care should be encouraged ${ }^{(18)}$.

The moment of hospital discharge of NB that experiences KMCM is an event expected and feared by families. Feelings are mixed up between family belonging and fear about the role of caregiver (father, mother, ...). KMCM is a technology that provides protection to the child, since more empowered family members feel safe and confident to perform care, maintain breastfeeding and identify warning signs.

Nurses stands out with its profile as a multiplier of the Method, while facing care and management challenges in $\mathrm{NU}^{(25-45)}$. Management participation proved to be fundamental to ensure method dissemination and strengthening as a public health policy ${ }^{(20,35)}$.

Every paradigm shift must be planned, tested and assessed. Historical approaches allow us to trace the method's achievements and challenges. Even in services that have strategies associated with KMCM such as programs and policies focusing on humanization, KMCM establishment presents difficulties. Studies are needed to strengthen the nursing team's performancein this aspect, aiming to find care strategies.

\section{Study limitations}

The limitations of this study correspond to the exclusive analysis of thesis and dissertation abstracts. Research that investigates KMCM-related productions in other health graduate programs is necessary, considering the recommended multidisciplinary approach to the method.

\section{Contributions to nursing, health or public policy}

There has been knowledge resultconstruction from competent human resources in the investigative process for more qualified care. Research development is an important strategy for strengthening nursing as a science and profession in its generalities and specialties. Thus, there is scope for action and study possibilities to be developed by nurses in KMCM. Therefore, the theme can be deepened and better applied in practice, providing a high quality of care to parents and low birth weight preterm infants, as well as favoring strengthening of this important public health policy.

\section{FINAL CONSIDERATIONS}

This study enabled the identification and characterization of doctoral theses and master'sdissertations developed in Brazilian StrictoSensu Graduate Nursing Programs addressing KMCM from 2000 to 2017.

Through the obtained results, it was possible to show that most of studies are qualitative. It makes use of comprehensive theoretical-philosophical frameworks, that is, one that allows understanding the phenomena from the perspective of the subjects participating in the studies.

The Graduate Nursing Programs with the largest number of productions related to KMCM are concentrated in the South, Southeast and Northeast of Brazil. It is also noted that the frequency of papers addressing this theme was not constant, with a higher concentration in 2006 and 2014. On the other hand, it was also observed that there were other years in which nothing was produced on the subject.

These data show that despite investment and government incentives, besides the efforts to enable KMCM establishment in institutions, there is no significant correspondence of studies on the theme. However, we can see a gap that needs to be filled, as we believe that further and in-depth studies need to be carried out in view of value and importance of KMCM for the survival and improvement of the quality of preterm and lowweight NB care. In addition, it is necessary to develop studies to follow up the clinical outcomes of these NB/families treated at KMCM in different Brazilian institutions.

\section{FUNDING}

This study was financed in part by the Coordenação de Aperfeiçoamento de Pessoal de Nível Superior - Brasil (CAPES) Finance Code 001. 


\section{ERRATUM}

Article "Kangaroo-mother care method: a documentary study of theses and dissertations of the brazilian nurse (20002017)", with number of DOI: http://dx.doi.org/10.1590/0034-7167-2018-0598, published in the journal Revista Brasileira de Enfermagem, 73(2):e20180598, on page 1:

Where to read:

Luana Cláudia dos Passos Aires'

ORCID: 0000-0003-3043-2018

\section{Claudia Koch'}

ORCID: 0000-0001-7191-5302

\section{Evangelia Kotzias Atherino dos Santos ORCID: 0000-0002-5970-020X}

Roberta Costa'

ORCID: 0000-0001-6816-2047

Janifer Souza Mendes'

ORCID: 0000-0002-5990-7884

Graciela Mendonça da Silva de Medeiros'

ORCID: 0000-0001-5438-057X

' Universidade Federal de Santa Catarina. Florianópolis, Santa Catarina, Brazil.
Read:

Luana Cláudia dos Passos Aires'

ORCID: 0000-0003-3043-2018

Claudia Koch"

ORCID: 0000-0001-7191-5302

Evangelia Kotzias Atherino dos Santos"' ORCID: 0000-0002-5970-020X

Roberta Costa"'

ORCID: 0000-0001-6816-2047

Janifer Souza Mendes'

ORCID: 0000-0002-5990-7884

Graciela Mendonça da Silva de Medeiros"'"

ORCID: 0000-0001-5438-057X

' Faculdade IELUSC. Joinville, Santa Catarina, Brazil.

"Secretaria do Estado da Saúde. Florianópolis, Santa Catarina, Brazil.

I' Universidade Federal de Santa Catarina. Florianópolis, Santa

Catarina, Brazil.

\section{REFERENCES}

1. World Health Organization (CH). Born too soon. The Global Action Report on Preterm Birth. [Internet]. Geneva: WHO; 2012 [cited 2018 Jun 3]. Report No.: 31-2581-12. Available from: http://www.who.int/pmnch/media/news/2012/201204_borntoosoon-report.pdf

2. Ministério da Saúde (BR). Secretaria de Atenção à Saúde. Departamento de Ações Programáticas Estratégicas. Atenção Humanizada ao Recém-Nascido [Internet]. Brasília: MS; 2017 [cited 2018 Jun 3]. Available from: http://bvsms.saude.gov.br/bvs/publicacoes/atencao_ humanizada_metodo_canguru_manual_3ed.pdf

3. Sanches MTC, Costa R, Azevedo VMGO, et al. Método Canguru no Brasil: 15 anos de política. II. São Paulo: Instituto de Saúde; 2015.

4. Conde-Agudelo, Agustin Díaz-Rossello JL. Kangaroo mother care to reduce morbidity and mortality in low birthweight infants. Vol. 2016, Cochrane Database of Systematic Reviews. 2016.

5. Ministério da Saúde (BR). Portaria no 693, de 5 de julho de 2000. Normas de Orientação para a Implantação do Método Canguru. Diário Oficial da União. 2000;(06 Jul).

6. Ministério da Saúde (BR). Portaria no 1.683, de 12 de julho de 2007. Aprova, na forma do Anexo, a Normas de Orientação para a Implantação do Método Canguru. Diário Oficial da União. 2007;(13 Jul).

7. Ministério da Saúde (BR). Portaria no 930/GM, de 10 de maio de 2012. Define as diretrizes e objetivos para a organização da atenção integral e humanizada ao recém-nascido grave ou potencialmente grave e os critérios de classificação e habilitação de leitos de Unidade Neonatal no âmbito do Sistema Único de Saúde (SUS). Diário Oficial da União. 2012;(11 Mai).

8. Ministério da Saúde (BR). Portaria no 3.389/GM, de 30 de dezembro de 2013. Altera, acresce e revoga dispositivos da Portaria no 930/GM/ MS, de 10 maio de 2012, que define as diretrizes e objetivos para a organização da atenção integral e humanizada ao recém-nascido grave ou potencialmente grave e os critérios de classificação e habilitação de leitos de Unidade Neonatal no âmbito do Sistema Único de Saúde (SUS). Diário Oficial da União. 2013;(31 Dez).

9. Ministério da Saúde (BR). Portaria no 1.459/GM/MS, de 24 de junho de 2011. Institui, no âmbito do Sistema Único de Saúde - SUS - a Rede Cegonha. Diário Oficial da União. 2011;(27 Jun).

10. Ministério da Saúde (BR). Portaria $\mathrm{n}^{\circ}$ 1.130, de 5 de agosto de 2015. Institui a Política Nacional de Atenção Integral à Saúde da Criança (PNAISC) no âmbito do Sistema Único de Saúde (SUS). Diário Oficial da União. 2015;(06 Jul). 
11. Padilha MI, Lígia M, Nelson S, Maia ARC, Costa R. O uso das fontes na condução da pesquisa histórica. 2017 [cited 2018 Jun 11];26(4):1-10. Available from: http://www.scielo.br/pdf/tce/v26n4/0104-0707-tce-26-04-e2760017.pdf

12. Leal MC, Szwarcwald CL, Almeida PVB, Mazera MS, Borenstein MS. Oral history and documental investigation as a research itinerary in nursing: a bibliometric study (2000-2014). Esc Anna Nery[Internet]. 2016 [cited 2018 Jun 3];20(4):1915-28. Available from: http://www. scielo.br/pdf/ean/v20n4/en_1414-8145-ean-20-04-20160087.pdf

13. Ministério da Educação (BR). Capes. Catálogo de Teses e Dissertações [Internet]. Brasília: Fundação CAPES. Ministério da Educação; 2016 [cited 2018 Jun 06]. Available from: http://catalogodeteses.capes.gov.br/catalogo-teses/\#!/

14. Geovanesi RE. Conhecimento, aceitação e disponibilidade dos profissionais de saúde sobre o método mãe canguru em unidade neonatal de um hospital universitário do município de São Paulo [Dissertação]. [São Paulo]: Universidade Federal de São Paulo; 2011.

15. Furlan CEFB. Implantação do Método Mãe-Canguru: percepção do enfermeiro e dos pais sobre a vivência [Dissertação]. [São Paulo]: Universidade de São Paulo; 2002.

16. Laise Conceição Caetano, Carmen Gracinda Silvan Scochi MA. Vivendo no Método Canguru: a tríade mãe-filho-família [Tese]. Escola de Enfermagem de Ribeirão Preto; 2004.

17. Freitas J de O. Método mãe-canguru: evolução ponderal de recém-nascidos [Dissertação]. [Salvador]: Universidade Federal da Bahia; 2005.

18. Costa R. Reflexões da equipe de saúde sobre o método mãe-canguru em uma unidade de neonatologia: um diálogo fundamentado na abordagem problematizadora [Dissertação]. [Florianópolis]: Universidade Federal de Santa Catarina; 2005.

19. Ribeiro AG. O Sentido do ser-mulher-puérpera no método mãe canguru [Dissertação]. [Salvador]: Universidade Federal da Bahia; 2006.

20. Gontijo TL. Avaliação normativa da implantação do Método Canguru na Maternidade Odete Valadares, Belo Horizonte, Minas Gerais [Dissertação]. [Belo Horizonte]: Universidade Federal de Minas Gerais; 2006.

21. Guimarães GP. A formação do apego pais/recém-nascido pré-termo e/ou de baixo peso no método mãe-canguru: uma contribuição da enfermagem [Dissertação]. [Florianópolis]: Universidade Federal de Santa Catarina; 2006.

22. Silva LJ da. Encontros Afetivos Entre Pais e Bebê no Espaço Relacional da Unidade Neonatal: um estudo de caso à luz do Método MãeCanguru [Dissertação]. [Rio de Janeiro]: Universidade Federal do Rio de Janeiro; 2007.

23. Borck M. Terceira Etapa Do Método Mãe-Canguru: convergência de práticas investigativas e cuidado no processo de adaptação de famílias com recém-nascidos pré-termo e/ou de baixo peso [Dissertação]. [Florianópolis]: Universidade Federal de Santa Catarina; 2007.

24. Morais AC, Quirino MD, Almeida MS. O cuidado da criança prematura no domicílio [Dissertação]. [Salvador]: Universidade Federal da Bahia; 2008.

25. Dantas ALB. O sentido do cuidado para mães no método canguru [Dissertação]. Universidade Federal de Piauí; 2011.

26. Silva LJ da. Sendo um Multiplicador de Valores e Práticas para a (Des) Continuidade do Método Canguru na Unidade de Terapia Intensiva Neonatal: subsídios para a gerência do cuidado de enfermagem [Tese]. [Rio de Janeiro]: Universidade Federal do Rio de Janeiro; 2013.

27. Silva JMQ. Significado para mães sobre a vivência no método canguru [Dissertação]. [Salvador]: Universidade Federal da Bahia; 2014.

28. Brazão BD. O acolhimento materno no contexto da prematuridade em um Hospital Amigo da Criança [Dissertação]. [Ribeirão Preto]: Universidade de São Paulo (Ribeirão Preto); 2014.

29. Stelmak AP. Algoritmos de Cuidado de Enfermagem Fundamentados no Método Canguru: uma construção participativa [Dissertação]. [Curitiba]: Universidade Federal do Paraná; 2014.

30. Mendes KM. Participação materna no método canguru ao recém-nascido pré-termo muito baixo peso internado na unidade de terapia intensiva neonatal [Dissertação]. [Recife]: Universidade de Pernambuco; 2015.

31. Aires LC dos P. Percepções dos Profissionais de Saúde da Atenção Básica Sobre o Seguimento do bebê Pré-Termo e/ou Baixo Peso e à sua Família: interfaces com a terceira etapa do Método Canguru [Dissertação]. [Florianópolis]: Universidade Federal de Santa Catarina; 2015.

32. Sales IMM. Alta hospitalar do recém-nascido submetido ao método canguru: contribuições da enfermagem [Dissertação]. [Teresina]: Universidade Federal do Piauí; 2017.

33. Canedo MC. Método Canguru: A experiência dos pais de recém-nascidos com baixo peso [Dissertação]. [Campo Grande]: Fundação Universidade Federal de Mato Grosso do Sul; 2017.

34. Batista TNL. Método Canguru: (des) atenção ao binômio mãe-bebê na estratégia saúde da família [Dissertação]. [João Pessoa]: Universidade Federal da Paraíba; 2017.

35. Borck M. Cuidado Compartilhado do Método Canguru na Atenção Básica de Saúde em Florianópolis [Tese]. [Florianópolis]: Universidade Federal de Santa Catarina; 2017.

36. Araújo JP, Silva RMM, Collet N, Neves ET, Toso BRGO,Viera CS. História da saúde da criança: conquistas, políticas e perspectivas. Rev Bras Enferm [Internet]. 2014 [cited 2018 Jun 27];67(6):1000-07. Available from: http://www.scielo.br/pdf/reben/v67n6/0034-7167reben-67-06-1000.pdf

37. Leal M do C, Szwarcwald CL, Almeida PVB, Aquino EML, Barreto ML, Barros F, et al. Saúde reprodutiva, materna, neonatal e infantil nos 30 anos do Sistema Único de Saúde (SUS). Cienc Saúde Coletiva [Internet]. 2018 [cited 2018 Jun 27];23(6):1915-28. Available from: http://www. scielo.br/pdf/csc/v23n6/1413-8123-csc-23-06-1915.pdf

38. Erdmann AL, Fernandes JD, Teixeira GA. Panorama da educação em enfermagem no Brasil: graduação e pós-graduação. Enferm Foco 
[Internet]. 2011 [cited 2018 Jun 27];2:89-93. Available from: http://revista.portalcofen.gov.br/index.php/enfermagem/article/view/91

39. Scochi CGS, Gelbcke FL, Ferreira MA, Lima MADS, Padilha KG, Padovani NA, et al. Doutorado em enfermagem no brasil: formação em pesquisa e produção de teses. Rev Latino-Am Enfermagem [Internet]. 2015 [cited 2018 Jun 27];23(3):387-94. Available from: http://www. scielo.br/pdf/rlae/v23n3/0104-1169-rlae-23-03-00387.pdf

40. Bernardo FR, Zucco LP. A centralidade do feminino no método canguru. Sex Salud Soc (Rio Janeiro) [Internet]. 2015 [cited 2018 Jun 27];(21):154-74. Available from: http://www.scielo.br/pdf/sess/n21/1984-6487-sess-21-00154.pdf

41. Aires LCP, Santos EKA, Costa R. Seguimento do bebê na atenção básica: interface com a terceira etapa do método canguru. Rev Gaúcha Enferm [Internet]. 2015 [cited 2018 Jun 3];36(spe):224-32. Available from: http://www.scielo.br/pdf/rgenf/v36nspe/en_0102-6933-rgenf-36spe-0224.pdf

42. Aires LCP, Santos EKA, Bruggemann OM, Backes MTS, Costa R. Referência e contrarreferência do bebê egresso da unidade neonatal no sistema de saúde: percepção de profissionais de saúde da Atenção Primária. Esc Anna Nery[Internet]. 2017 [cited 2018 Jun 6];21(2):1-7. Available from: http://www.gnresearch.org/doi/10.5935/1414-8145.20170028

43. Antunes BS, Paula CC, Padoin SMM, Trojahn TC, Rodrigues AP, Tronco CS. Internação do recém-nascido na Unidade Neonatal: significado para a mãe. Rev RENE [Internet]. 2014 [cited 2018 Jun 11];15(5):796-803. Available from: http://www.revistarene.ufc.br/revista/index.php/ revista/article/view/1794/pdf_1

44. Custódio ZAO, Crepaldi MA, Linhares MBM. Redes sociais de apoio no contexto da prematuridade: perspectiva do modelo bioecológico do desenvolvimento humano. Estud Psicol [Internet]. 2014[cited 2018 Jun 11];31(2):247-55. Available from: http://www.scielo.br/pdf/estpsi/ v31n2/a10v31n2.pdf

45. Silva LJ, Leite JL, Scochi CGS, Silva LR, Silva TP. A adesão das enfermeiras ao Método Canguru: subsídios para a gerência do cuidado de enfermagem. Rev Latino-Am Enfermagem [Internet]. 2015 [cited 2018 Jun 11];23(3):483-90. Available from: http://www.scielo.br/pdf/rlae/ v23n3/0104-1169-rlae-0339-2579.pdf 